\title{
Małgorzata Okupnik, W niewoli ciała. Doświadczenie utraty zdrowia i jego reprezentacje, Wydawnictwo: Universitas, Kraków 2018, ss. 553 (rec. Maria Ciesielska)
}

W 2018 r. ukazała się nakładem wydawnictwa Universitas książka Małgorzaty Okupnik pt. W niewoli ciała. Doświadczenie utraty zdrowia $i$ jego reprezentacje. Autorka jest doktorem nauk humanistycznych, absolwentką filologii polskiej i kulturoznawstwa Uniwersytetu im. Adama Mickiewicza w Poznaniu, wykładowczynią Akademii Muzycznej im. I.J. Paderewskiego w Poznaniu oraz autorką monografii Autobiografie polskich sportowców samotników (2005) oraz licznych artykułów naukowych na tematy autobiografizmu, badań biograficznych, pamięci, doświadczenia utraty.

Recenzentami publikacji byli prof. dr hab. Bogumiła Kaniewska oraz dr hab. Izolda Topp-Wójtowicz, która napisała następujące słowa na temat tej publikacji: „Tym, co w mojej opinii decyduje o oryginalności pracy, jest nowy sposób ujęcia tej problematyki, oglądanej w perspektywie wiążącej utratę i dar. W tej właśnie perspektywie, na tle uznawanego dziś powszechnie za prywatne doświadczenia utraty zdrowia, autorka zwraca uwagę na twórcze przezwyciężenie jej skutków (w narracjach i pracach plastycznych)".

„Celem tej książki” - jak deklaruje autorka - ,jest omówienie reprezentacji doświadczenia utraty zdrowia wskutek poważnej, przewlekłej, somatycznej, nieuleczalnej choroby" (s. 16). Ale choroba jako taka nie jest główną bohaterką rozważań. Czytelnik nie odnajdzie tu zmedykalizowanego dyskursu ani też licznych odwołań do fizyczności procesu chorowania i umierania. Nawet w tytule książki autorka rezygnuje ze słowa „choroba”, zastępując je „utratą zdrowia”, tym samym dając nam jasno do zrozumienia, w jakim obszarze semantycznym będzie się poruszała.

Książka składa się - obok wstępu i zakończenia - z trzech rozdziałów. W części pierwszej - O utracie - autorka podjęła za pomocą analizy fenomenologicznej próbę definicji utraty, odwołując się do prac z zakresu psychologii, antropologii, kulturoznawstwa, filozofii, jak 
i opracowań słownikowych czy Biblii. Zastanawiając się nad istotą utraty, Małgorzata Okupnik wyróżnia „utratę” i „stratę”. Utratę rozumie jako stan, w jakim znajduje się ,ja” w sytuacji krytycznej: śmierci bliskiego i śmiertelnej choroby (pociągających za sobą serię innych utrat i strat). Utrata pozostawia rany i trwałe ślady, ponieważ jest doświadczeniem destrukcyjnym i zawsze związanym z najgłębszymi emocjami (miłością, przywiązaniem i bliskością). Istotą doświadczenia utraty jest zdaniem autorki sposób, w jaki ,ja” doświadcza świata i siebie samego w wydarzeniu, jakim jest zerwanie więzi i konieczność przekształcenia ,ja” relacyjnego w ,ja” indywidualne. Fakt, że utraconego nie można odzyskać, odróżnia utratę od straty. Mimo że utrata wydaje się raczej zjawiskiem indywidualnym to autorka zauważa także zjawisko traumy zbiorowej następującej w trakcie działań wojennych, klęsk żywiołowych, ataków terrorystycznych, a nawet śmierci autorytetów społecznych, jak choćby po odejściu Jana Pawła II. Jak podkreśla Małgorzata Okupnik, analiza żałoby zbiorowej jest zjawiskiem trudnym ze względu na złożoność tragedii w wymiarze społecznym, politycznym czy międzynarodowym.

Rozdział drugi Reprezentacje doświadczenia utraty zdrowia dotyczy kulturowego wymiaru doświadczenia utraty zdrowia. Podwójne kompetencje autorki - w zakresie kulturoznawstwa, jak i filologii polskiej - umożliwiły prezentację wybranych patografii, a właściwie, jak chce Małgorzata Okupnik, kancerografii, czyli autobiograficznych świadectw dotyczących walki z chorobą nowotworową. Warto jednak zauważyć, że problem semiotycznej nieprzekładalności stanowi w dyskursie maladycznym wyraźne ograniczenie. Biologiczne objawy choroby nie poddają się łatwemu przełożeniu na język dzieł sztuki. Jak pisze Mateusz Szubert, blokada ta wynika z różnicy systemów. Co więcej, podkreśla on, iż na przestrzeni ostatnich 2000 lat na ogó1 nie epatowano własnym cierpieniem. W kulturze antycznej właściwie w ogóle nie mówiło się o cierpieniu własnym. Szkoły filozoficzne marginalizowały temat indywidualnego cierpienia, uniwersalizując go; podobnym milczeniem zbywano chorobę (poza epidemiami). Autorzy średniowieczni, opierając się na starotestamentowej egzegezie cierpienia, uznali, że choroba jest karą za grzechy i jednocześnie jedyną formą możliwości oczyszczenia z nich. W okresie renesansu cierpienie fizyczne stało się wręcz pouczającym środkiem wymierzania kary, będąc równocześnie przedmiotem społecznej ciekawości, a niekiedy także drwiny i niewybrednych żartów. Dopiero romantyczny indywidualizm, poprzedzony oświeceniowym zwróceniem uwagi na 
człowieka jako jednostkę, stał się momentem zwrotnym, inicjującym nowe spojrzenie na chorego. Wraz z początkiem XIX w. zmieniły się wzory patrzenia na cierpienie, $w$ tym cierpienia wywołanego chorobą, a dyskurs maladyczny ewoluował w kierunku autonomizacji cierpienia, skupiając się na losie pojedynczego człowieka ${ }^{1}$.

$\mathrm{W}$ rozdziale trzecim badaczka poddała analizie patografie i prace plastyczne tworzone przez osoby chore (na nowotwory złośliwe, stwardnienie boczne zanikowe, degenerację siatkówki). Ale także świadectwa osób, które towarzyszyły bliskiemu zmagającemu się z nieuleczalną chorobą. Wspomniane już kompetencje badaczki ułatwiły jej niewątpliwie wybór tekstów i ich badanie. Małgorzata Okupnik sięgnęła po 68 patografii, m.in. Krystyny, Jerzego Stuhrów, ks. Józefa Tischnera czy Agaty Tuszyńskiej, jak i blogi, np. bloga Joanny Sałygi, czy filmy. Bibliografia zawiera ponad 550 pozycji piśmiennictwa.

W niewoli ciała. Doświadczenie utraty zdrowia i jego reprezentacje jest książką ciekawą dla każdego dojrzałego czytelnika, być może także dla lekarzy o zamiłowaniach humanistycznych. Niemal każda karta tej publikacji skłania do refleksji i przywołuje własne doświadczenia, jak i te nabyte w pracy zawodowej. Wielość znaczeń i budzących się podczas lektury emocji powoduje, że każdy czytelnik może interpretować zamieszczone w pracy kancerografie indywidualnie, zgodnie ze swoim zapleczem intelektualnym i nabytym doświadczeniem. W swoim eseju Choroba jako metafora Susan Sontag odradzała praktyki interpretacyjne, uznając, że jedynym właściwym obliczem choroby jest jej strona medyczna. Taki sposób myślenia jest bliski każdemu lekarzowi. Tymczasem Małgorzata Okupnik skutecznie przeciwstawiła się takiemu dyskursowi, dowodząc, że jej przepełniona empatią sztuka interpretowania pozwala odczytać na nowo sens utraty.

${ }^{1}$ M. Szubert, Gruźlica w dyskursie maladycznym, „Postscriptum Polonistyczne” 2008, nr 2(2), s. 101. 